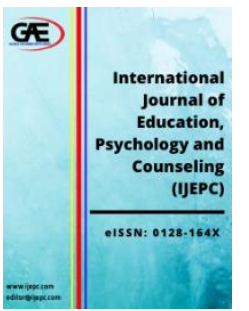

\author{
INTERNATIONAL JOURNAL OF \\ EDUCATION, PSYCHOLOGY \\ AND COUNSELLING \\ (IJEPC) \\ www.ijepc.com
}

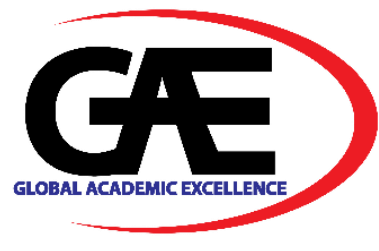

\title{
THE EXPERIENCES OF PRE-SERVICE TEACHERS TEACHING PRACTICUM DURING THE COVID-19 PANDEMIC: A SYSTEMATIC LITERATURE REVIEW
}

\author{
Prescylla Kristyn Kiok ${ }^{1}$, Wardatul Akmam Din ${ }^{2 *}$, Noraini Said ${ }^{3}$, Suyansah Swanto ${ }^{4}$ \\ 1 Faculty of Psychology and Education, Universiti Malaysia Sabah, Malaysia \\ Email: pres.kiok@gmail.com \\ 2 Faculty of Psychology and Education, Universiti Malaysia Sabah, Malaysia \\ Email: wardadin@ums.edu.my \\ 3 Faculty of Psychology and Education, Universiti Malaysia Sabah, Malaysia \\ Email: noraini.said@ums.edu.my \\ 4 Faculty of Psychology and Education, Universiti Malaysia Sabah, Malaysia \\ Email: suyansah@ums.edu.my \\ * $\quad$ Corresponding Author
}

\section{Article Info:}

Article history:

Received date: 11.09.2021

Revised date: 10.10 .2021

Accepted date: 15.11 .2021

Published date: 30.11 .2021

To cite this document:

Kiok, P. K., Din, W. A., Said, N., Swanto, S. (2021). The Experiences of Pre-service Teachers Teaching Practicum During the COVID-19 Pandemic: A Systematic Literature Review. International Journal of Education, Psychology and Counseling, 6 (43), 280-295.

DOI: $10.35631 /$ IJEPC.643022

This work is licensed under $\mathrm{CC}$ BY 4.0

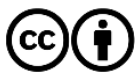

\begin{abstract}
:
The COVID-19 pandemic has resulted in the prohibition of close contact and this unprecedented issue has led to the abrupt closure of schools and universities across the country. Teacher education programs have taken a toll as the final year students would not be able to fully experience the working environment in a school during teaching practicum. Thus, this systematic literature review aims to explore the lived experiences of pre-service teachers teaching practicum experiences during the COVID-19 pandemic. Hence, after screening from 23,084 research articles, 8 relevant articles that focus on the teaching practicum experiences of pre-service teachers during the pandemic were chosen for review in order to achieve the objective. The findings show that the pre-service teachers teaching practicum experiences can be categorised into intrapersonal development or interpersonal development. Pre-service teachers seem to have a positive perception towards the change as they understood the importance of the transition from face-to-face learning to online learning during the pandemic. Other than that, positive or negative teaching practicum experiences highly depend on the institutions as much as the pre-service teachers depend on themselves. The future agenda and implementation of the findings are also discussed.
\end{abstract}

Keywords:

Teaching Practicum, Pre-service Teachers, Experiences, Pandemic 


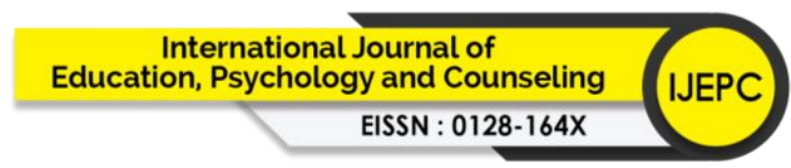

Volume 6 Issue 43 (November 2021) PP. 280-295

DOI 10.35631/IJEPC.643022

\section{Introduction}

Special Issue: Issues and Challenges in English Education

The COVID-19 outbreak was declared a pandemic by the World Health Organisation (WHO) on $12^{\text {th }}$ March 2020 and various changes can be seen as an impact from the pandemic since. The 2019 novel coronavirus (2019-nCoV) or the severe acute respiratory syndrome corona virus 2 (SARS-CoV-2) as it is now called, is rapidly spreading from its origin in Wuhan City of Hubei Province of China to the rest of the world (Singhal, 2020). The future course of this virus is undeniably unknown and cannot be predicted. Moreover, various variants have developed over time. This has impacted the lives of many in more ways than initially imagined and most likely lockdowns and the prohibition of social activities will be prolonged.

Due to the sudden coronavirus pandemic, the education sector has greatly been affected due to the prohibition of close contact and mass gathering to prevent the spread of the virus. This has led to the abrupt closure of schools and universities across the country and the whole world. This unprecedented issue has caused many institutions to struggle in handling teaching and learning as well as lack of clarity in administering students' assessment. The face-to-face education has shifted to online platforms as the conventional classroom-settings are unavailable. The COVID-19 global pandemic has altered the design and structure of our traditional education programs, and teacher education is no exception (Baran \& Alzoubi, 2020). Therefore, this is a huge issue for teacher education programs as the final year students would not be able to fully experience the working environment in a school during teaching practicum.

Teaching practicum (TP) is an important stage for teacher education programs as it is highly valued by pre-service teachers (PSTs), mentor teachers (MTs) and university supervisors (USs). During the teaching practicum, both the mentor teacher and university supervisor will be guiding the PST in their professional development. Ensuring the PSTs are able to practice and experiment with their pedagogical knowledge as well as developing and executing lesson plans effectively. The practicum is an opportunity for pre-service teachers to link theory with practice in an authentic classroom setting (Ersin, Atay \& Mede, 2020).

There is the possibility that education will mainly be online in the near future, hence the need to explore pre-service teachers' online learning experiences to understand how to help them to learn online and prepare them to effectively teach online in the future (Ogbonnaya, Awoniyi \& Matabane, 2020). According to Sasaki et al. (2020), early investigations suggest that technology-based simulated environments may supplement and support the Initial Teacher Education (ITE) practicum experience, and now particularly during the Covid-19 pandemic. This may act as a guide for future studies to comprehend the issue and possible struggles of the abrupt transition to online learning, thereby perhaps accommodating any future challenges faced by any educational institutions.

The perspective of pre-service teachers (PSTs) undergoing teaching practicum (TP) during a new normal where the traditional classes as sites of teaching and learning are not available, face-to-face interaction and gatherings are prohibited and supervision from mentor and lecturer are limited. Unprecedented and unprepared to the new normal of online teaching delivery, PSTs must adapt and find ways to ensure they gain professional learning and achieve preparedness for the teaching profession. Thus, this systematic literature review aims 


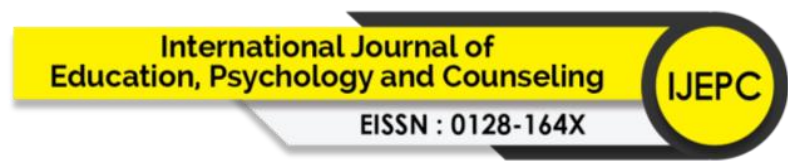

Volume 6 Issue 43 (November 2021) PP. 280-295

DOI 10.35631/IJEPC.643022

Special Issue: Issues and Challenges in English Education to explore the experiences of pre-service teachers teaching practicum during the COVID-19 pandemic. The literatures are mapped to understand what lessons learned from the past and discuss the possible future scenario and finally provide a future agenda. This systematic literature review will aim to answer the following research question: "What are the lived experiences of pre-service teachers teaching practicum experiences during the COVID-19 pandemic?". Hence, researches that focus on the teaching practicum experiences of preservice teachers during the pandemic will be chosen for review in order to achieve the objective.

\section{Methodology}

The paper will conduct a systematic literature review where it differs from traditional narrative review. It helps to collect all related publications and documents that fit our predefined inclusion criteria to answer a specific research question (Mengist, Soromessa \& Legese, 2020). The first step in this systematic literature review is identifying vital keywords and phrases in order to answer the research objectives. The keywords considered are "teaching practice" or "teaching practicum", "pre-service teachers" or "student teachers" and "COVID-19". The keywords were searched on Universiti Malaysia Sabah subscribed databases to obtain the relevant articles. The readers read the articles in a fair and objective manner to achieve the aim of the paper.

\section{The Search Strategy}

The review was done by using the UMS Library subscribed databases. Scopus and ProQuest were used to search the relevant research articles. Keywords like "teaching practicum" and "pre-service teachers" were used on the subscribed databases to obtain a list of relevant studies. The first inclusion criterion was that the articles were published within the timeframe from 2020 to 2021. This is to ensure the studies were relevant to the COVID-19 pandemic. The next inclusion is that the articles were in English. Other than that, the search was limited to only full text journal articles or scholarly articles for the document type criteria. The flowchart in Figure 1 below shows the study inclusion and exclusion process.
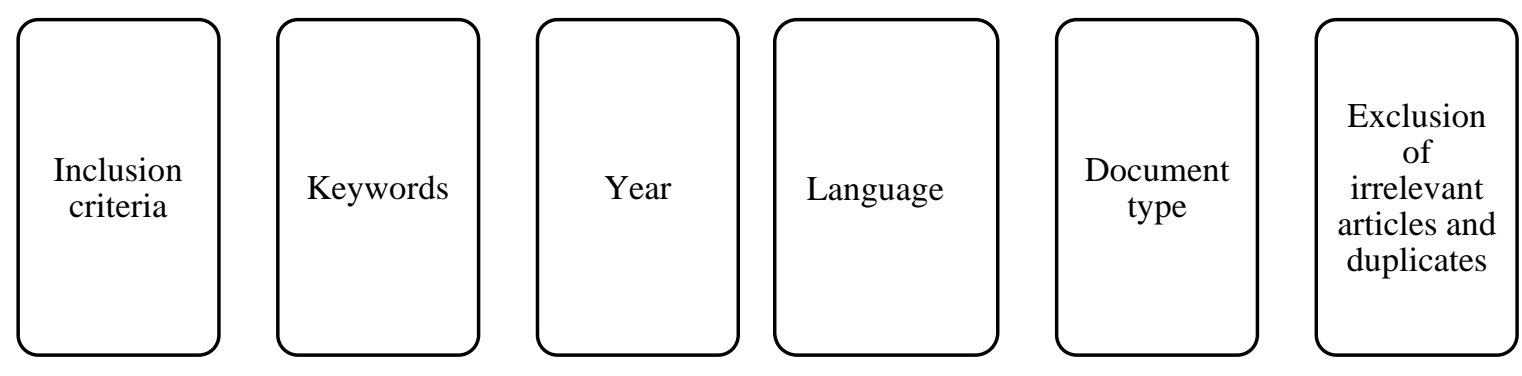

\section{Figure 1: Flow Chart of the Inclusion and Exclusion Process}

There were a total of 23,084 articles found by searching "teaching practice" or "teaching practicum" where there are 15,757 articles from Scopus and 7,327 articles from ProQuest. To retrieve relevant articles, the keywords "pre-service teachers" or "student teachers" and "COVID-19" were considered as the inclusion criteria. There were 559 articles left from the databases where Scopus had 12 articles and ProQuest had 547 articles. The results were then limited by the publication year 2020 and 2021, and there are 291 articles left where Scopus had 12 articles and ProQuest had 279 articles. From this, the inclusion criteria of language, 


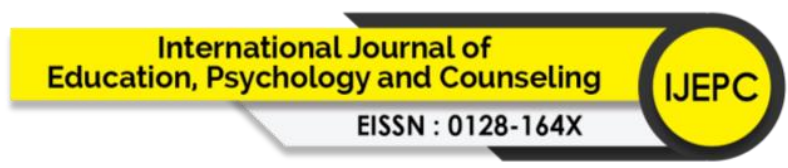

Volume 6 Issue 43 (November 2021) PP. 280-295

DOI 10.35631/IJEPC.643022

Special Issue: Issues and Challenges in English Education where English was the desired language, has resulted in only 268 articles left with 6 articles and 262 articles from Scopus and ProQuest respectively. The final inclusion criteria before exporting the articles is the document type where only full text journal articles and scholarly articles were included. This inclusion then left only 48 articles where Scopus had 6 articles and ProQuest had 42 articles.

These articles were then exported from the databases to Microsoft Excel for easy access to further the screening process. To prevent repeated findings, 1 duplicate article was removed hence left a total of 47 articles for screening and to be reviewed. The review was conducted by analysing the title and abstract of each of the articles to determine its relevance to the research questions. Articles that were not relevant to the research question were excluded. After the review and screening process, there were only 9 articles left for retrieval. However, out of the 9 articles, 1 article full text was not available to access hence it is excluded from the systematic review. After reviewing all the articles in the full-text screening stage for eligibility, there are a total of 8 articles left.

Table 1: Inclusion Criteria of The Systematic Review

\begin{tabular}{cccc}
\hline $\begin{array}{c}\text { Inclusion } \\
\text { Criteria }\end{array}$ & Details & $\begin{array}{c}\text { Removed } \\
\text { articles }\end{array}$ & $\begin{array}{c}\text { Remaining } \\
\text { relevant } \\
\text { articles }\end{array}$ \\
\hline Key Terms & Teaching practices or teaching practicum & 23084 & 23084 \\
Keywords & pre-service teachers and COVID-19 & 22525 & 559 \\
Year & 2020 to 2021 & 268 & 291 \\
Language & English & 23 & 268 \\
Document type & Journal articles or scholarly articles & 220 & 48 \\
\hline
\end{tabular}

Table 2: Exclusion Criteria

\begin{tabular}{cccc}
\hline $\begin{array}{c}\text { Exclusion } \\
\text { Criteria }\end{array}$ & Details & $\begin{array}{c}\text { Removed } \\
\text { articles }\end{array}$ & $\begin{array}{c}\text { Remaining } \\
\text { relevant } \\
\text { articles }\end{array}$ \\
\hline Duplicate & Appeared more than once in results & 1 & 47 \\
Subject Area & Irrelevant subject area & 38 & 9 \\
No access & Unable to access to full text & 1 & 8 \\
\hline
\end{tabular}


Volume 6 Issue 43 (November 2021) PP. 280-295

DOI 10.35631/IJEPC.643022

Results

Table 3: Findings of Literature Review

\begin{tabular}{|c|c|c|c|c|c|}
\hline $\begin{array}{l}\mathbf{N} \\
\mathbf{0}\end{array}$ & $\begin{array}{c}\text { Author \& } \\
\text { Year }\end{array}$ & Title & $\begin{array}{c}\text { Count } \\
\text { ry }\end{array}$ & Method & Relevant Findings \\
\hline $\begin{array}{l}\mathrm{R} \\
\mathrm{A} \\
1\end{array}$ & $\begin{array}{l}\text { Nel P.C., } \\
\text { Marais } \\
\text { D.E. } \\
(2021)\end{array}$ & $\begin{array}{l}\text { Addressing } \\
\text { the wicked } \\
\text { problem of } \\
\text { feedback } \\
\text { during the } \\
\text { teaching } \\
\text { practicum }\end{array}$ & $\begin{array}{l}\text { South } \\
\text { Africa }\end{array}$ & $\begin{array}{l}\text { Qualitativ } \\
\text { e } \\
\text { Explorator } \\
\text { y Case } \\
\text { study }\end{array}$ & $\begin{array}{l}\text { The paper introduces a social annotation platform } \\
\text { called Perusall where pre-service teachers can } \\
\text { receive feedback from their supervisor and } \\
\text { mentor. The results indicated that pre-service } \\
\text { teachers, university supervisor as well as mentor } \\
\text { teachers were actively engaged "on the same } \\
\text { page" with constructive dialogic feedback that } \\
\text { assisted student teachers to make crucial } \\
\text { adjustments to the core practice of } \\
\text { explaining/modelling content. Thus, the study } \\
\text { shows providing feedback and having a reliable } \\
\text { platform for opportunities can overcome problems } \\
\text { during teaching practicum. }\end{array}$ \\
\hline
\end{tabular}

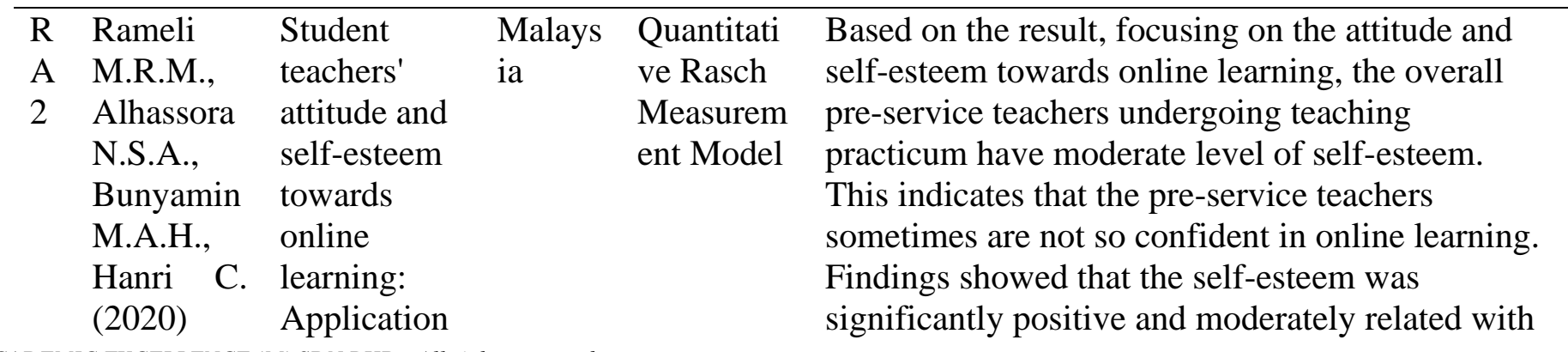


Volume 6 Issue 43 (November 2021) PP. 280-295

DOI 10.35631/IJEPC.643022

Special Issue: Issues and Challenges in English Education

of Rasch

measuremen

$\mathrm{t}$ model attitude towards the correlation coefficient .500 .

Pre-service teachers with high self-esteem show a

positive attitude towards online learning and vice

versa.

\begin{tabular}{|c|c|c|c|c|c|}
\hline $\begin{array}{l}\mathrm{R} \\
\mathrm{A} \\
3\end{array}$ & $\begin{array}{l}\text { Barnes R., } \\
\text { Hall R., } \\
\text { Lowe V., } \\
\text { Pottinger } \\
\text { C., } \\
\text { Popham } \\
\text { A. (2020) }\end{array}$ & $\begin{array}{l}\text { Lessons } \\
\text { from an } \\
\text { online } \\
\text { teacher } \\
\text { preparation } \\
\text { Program: } \\
\text { flexing work } \\
\text { experience } \\
\text { to meet } \\
\text { student } \\
\text { needs and } \\
\text { regulators' } \\
\text { RA4require } \\
\text { ments in the } \\
\text { United } \\
\text { States }\end{array}$ & $\begin{array}{l}\text { United } \\
\text { States }\end{array}$ & $\begin{array}{l}\text { Qualitativ } \\
\mathrm{e}\end{array}$ & $\begin{array}{l}\text { Western Governors University (WGU) compiled a } \\
\text { list of responses to COVID regarding teaching } \\
\text { practicum. Through diligent effort all the } \\
\text { candidates (pre-service teachers) were able to } \\
\text { complete their teaching practicum following the } \\
\text { response by WGU. WGU responded by allowing } \\
\text { parallelism between the pre-service teacher and } \\
\text { their mentor teacher so that the pre-service teacher } \\
\text { could engage in teaching in the same manner as } \\
\text { their mentor teacher, which varied on a district-by- } \\
\text { district and state-by-state basis. WGU was also } \\
\text { careful to evaluate whether the host school's } \\
\text { virtualisation was still meeting the needs of the } \\
\text { pre-service teacher and if not, then to shift the pre- } \\
\text { service teacher to a different placement that was } \\
\text { more virtual-friendly. }\end{array}$ \\
\hline $\begin{array}{l}\mathrm{R} \\
\mathrm{A} \\
4\end{array}$ & $\begin{array}{l}\text { Asghar, } \\
\text { Muhamma } \\
\text { d Zaheer; } \\
\text { Barberà, } \\
\text { Elena; }\end{array}$ & $\begin{array}{l}\text { Mobile } \\
\text { Learning } \\
\text { Technology } \\
\text { Readiness } \\
\text { and }\end{array}$ & $\begin{array}{l}\text { Pakista } \\
\mathrm{n}\end{array}$ & $\begin{array}{l}\text { Quantitati } \\
\text { ve cross- } \\
\text { sectional } \\
\text { survey }\end{array}$ & $\begin{array}{l}\text { The study investigates pre-service teachers' } \\
\text { accessibility, acceptability, and readiness towards } \\
\text { mobile learning technology. The results reveal that } \\
\text { the pre-service teachers showed a tendency } \\
\text { towards accepting and readiness of mobile }\end{array}$ \\
\hline
\end{tabular}


Volume 6 Issue 43 (November 2021) PP. 280-295

DOI 10.35631/IJEPC.643022

Special Issue: Issues and Challenges in English Education

$\begin{array}{ll}\text { Younas, } & \text { Acceptance } \\ \text { Iram } & \text { among Pre- } \\ \text { Asghar, } & \text { Service } \\ \text { Muhamma } & \text { Teachers in } \\ \text { d } & \text { Pakistan } \\ \text { Zaheer;Ba } & \text { during the } \\ \text { rberà, } & \text { COVID-19 } \\ \text { Elena; } & \text { Pandemic }\end{array}$

Younas,

Iram

(2021) learning as they believed it would ease students'

access to learning materials. Personal innovation,

quality of services, and social influence have a

significant direct impact on behavioural intention

to use mobile learning technology. Personal

innovation and quality of services have an indirect

effect on mobile learning readiness. On the

contrary, the study found a direct effect of effort

expectancy, performance expectancy, personal

innovation, quality of services, and behavioural

intentions on mobile learning readiness.

\begin{tabular}{lllll}
\hline R & Aguilar- & Pre-Service & Colom & Qualitativ \\
A & Cruz, & English & bia & e \\
5 & Paola & Teachers' & \\
& Julie;Medi & Perceptions & \\
na, Deicy & of Their & \\
Lorena & Online \\
& (2021) & Teaching & \\
& Practice \\
& during \\
& Pandemic \\
& Times
\end{tabular}

With the study investigating pre-service teachers' perceptions on online teaching practicum during the pandemic, the result shows that there are some pros and cons in the pre-service teachers' narratives. The pre-service teachers find their negative feelings mainly related to online practicum and their students' commitment. However, they embrace the role of technology and its importance for communication and learning. They find it a crucial factor in the teaching process because without it, they may not have the opportunity to undergo their teaching practicum. In other words, even though pre-service English teachers had to face different concerns related to their online teaching practicum, such as students' 
Volume 6 Issue 43 (November 2021) PP. 280-295

DOI 10.35631/IJEPC.643022

Special Issue: Issues and Challenges in English Education

lack of commitment, low motivation and

connectivity issues because of the pandemic, still

they were capable of understanding and reflecting

upon their role as teachers and used technology

and gamified activities to overcome their

concerns.

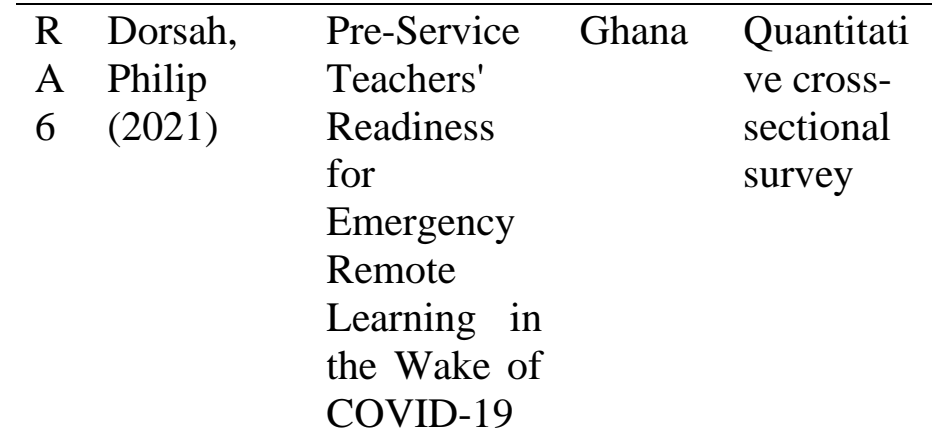

With the study investigating pre-service teachers' readiness for emergency remote learning, the result shows that the pre-service teachers were ready for online learning with overall readiness mean score of 3.65. The dimension with the highest mean score was motivation for learning $(\mathrm{M}=3.97, \mathrm{SD}=0.90)$ followed by self-directed learning $(\mathrm{M}=3.82, \mathrm{SD}=0.93)$. However, the dimensions of learner control $(\mathrm{M}=3.30, \mathrm{SD}=$ 1.00), computer/internet self-efficacy $(\mathrm{M}=3.43$, $\mathrm{SD}=1.16)$ and online communication selfefficacy $(\mathrm{M}=3.47, \mathrm{SD}=1.11)$ recorded low means. There was no significant difference in online learning readiness between males $(\mathrm{M}$ $=3.71, \mathrm{SD}=0.82)$ and females $(\mathrm{M}=3.57, \mathrm{SD}=$ $0.76), \mathrm{t}(0.94), \mathrm{p}=0.349$. Also, there was no significant difference in readiness between level 100 pre-service teachers $(\mathrm{M}=3.65, \mathrm{SD}=.79)$ and level 200 pre-service teachers $(\mathrm{M}=3.68, \mathrm{SD}=$ .85) t (-.122), p = .903. In other words, Pre-service 
Volume 6 Issue 43 (November 2021) PP. 280-295

DOI 10.35631/IJEPC.643022

Special Issue: Issues and Challenges in English Education teachers' readiness for online learning is high but low for readiness in learner control, computer/internet self-efficacy and online communication self-efficacy.

\begin{tabular}{|c|c|c|c|c|c|}
\hline $\begin{array}{l}\mathrm{R} \\
\mathrm{A} \\
7\end{array}$ & $\begin{array}{l}\text { Kim, } \\
\text { Jinyoung } \\
(2020)\end{array}$ & $\begin{array}{l}\text { Learning } \\
\text { and } \\
\text { Teaching } \\
\text { Online } \\
\text { During } \\
\text { Covid-19: } \\
\text { Experiences } \\
\text { of Student } \\
\text { Teachers in } \\
\text { an Early } \\
\text { Childhood } \\
\text { Education } \\
\text { Practicum }\end{array}$ & $\begin{array}{l}\text { United } \\
\text { States }\end{array}$ & $\begin{array}{l}\text { Qualitativ } \\
\text { e } \\
\text { Descriptiv } \\
\text { e study }\end{array}$ & $\begin{array}{l}\text { The study demonstrates how a pre-service } \\
\text { teacher's education course redesigned to provide } \\
\text { opportunities to learn and teach online. It } \\
\text { describes three phases of the online student } \\
\text { teachers' experiences-Preparation, } \\
\text { Implementation, and Reflection. Tasks } \\
\text { accomplished in each phase are reported. Online } \\
\text { teaching experiences provided these preservice } \\
\text { teachers with opportunities to interact with } \\
\text { children, as well as to encourage reflection on how } \\
\text { best to promote young children's development and } \\
\text { learning with online communication tools. Student } \\
\text { teachers' experiences for efficient online teaching } \\
\text { and learning can be supported by appropriate } \\
\text { instructional strategies in college courses for } \\
\text { teacher education, as well as through online } \\
\text { collaborations with schools and families. }\end{array}$ \\
\hline $\begin{array}{l}\mathrm{R} \\
\mathrm{A} \\
8\end{array}$ & $\begin{array}{l}\text { Tartavulea } \\
\text {, Cristina } \\
\text { Venera;Al } \\
\text { bu, }\end{array}$ & $\begin{array}{l}\text { ONLINE } \\
\text { TEACHING } \\
\text { PRACTICE } \\
\text { S AND THE }\end{array}$ & $\begin{array}{l}\text { Roman } \\
\text { ia }\end{array}$ & $\begin{array}{l}\text { Quantitati } \\
\text { ve } \\
\text { Questionn } \\
\text { aire-based }\end{array}$ & $\begin{array}{l}\text { The study investigates the impact of the abrupt } \\
\text { switch to online learning towards pre-service } \\
\text { teachers' teaching and learning . The result shows } \\
\text { that universities and students were very quick to }\end{array}$ \\
\hline
\end{tabular}


Volume 6 Issue 43 (November 2021) PP. 280-295

DOI 10.35631/IJEPC.643022

DOI 10.35631/IJEPC.643022
Special Issue: Issues and Challenges in English Education

$\begin{array}{ll}\text { Catalin } & \text { EFFECTIV } \\ \text { Nicolae;A } & \text { ENESS OF } \\ \text { lbu, } & \text { THE } \\ \text { Nadia;Die } & \text { EDUCATIO } \\ \text { aconescu, } & \text { NAL } \\ \text { Ramona } & \text { PROCESS } \\ \text { Iulia;Petre } & \text { IN THE } \\ \text {, Silvia } & \text { WAKE OF } \\ \text { (2020) } & \text { THE } \\ & \text { COVID-19 } \\ & \text { PANDEMI } \\ & \text { C }\end{array}$

survey adapt to the new changes and that a mix of

synchronous and asynchronous interaction and

assessment methods are currently employed.

However, this mix is quite limited relative to what

is usually subsumed into online learning tools, and

is indicative of passive delivery and reduced

interaction. Our respondents estimate that most

online interaction and assessment methods will

continue to be used after the return to face-to-face

education. Our respondents also view the switch to

online teaching to have an overall moderate

positive impact on the educational process, albeit

the overall effectiveness of the online educational

experience is perceived to be lower than in the

case of face-to-face teaching. Moreover, we find

that the institutional support, the trust in the online

system and the perceived effectiveness of

formative assessment are factors that are

positively associated with the impact and

effectiveness of online education. 
Characteristics of the Relevant Articles

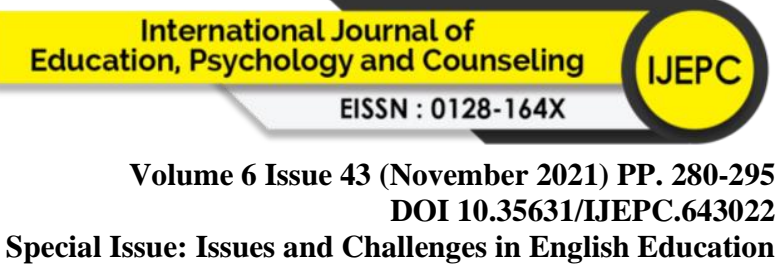

According to Creswell (2012), although all experiments have common characteristics, their use and applications vary depending on the type design used. The figure below shows the frequency of countries in the reviewed studies.

Figure 2: Frequency of Countries

\section{Countries involved in the Reviewed Articles}

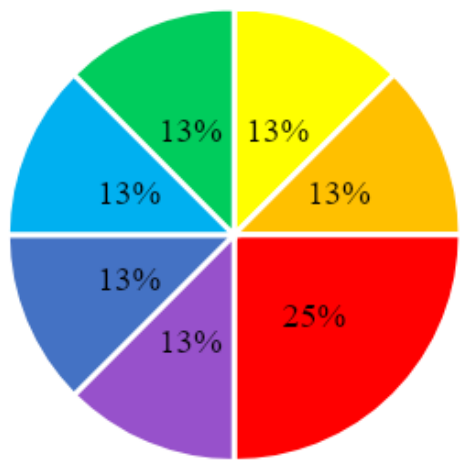

Malaysia

mouth Africa

- United States

- Pakistan

- Colombia

Ghana

- Romania

Based on the figure above, the relevant articles represented several countries. The countries that were represented in the reviewed articles are Malaysia, South Africa, United States, Pakistan, Colombia, Ghana and Romania. Out of the total 8 relevant articles selected for review, there are 1 article represented each country except for the United States where there are 2 articles thus making it the highest percentage of $25 \%$ and the rest equal percentage of $12.5 \%$.

The figure below shows the percentage of methods employed by the relevant articles used in the review. 

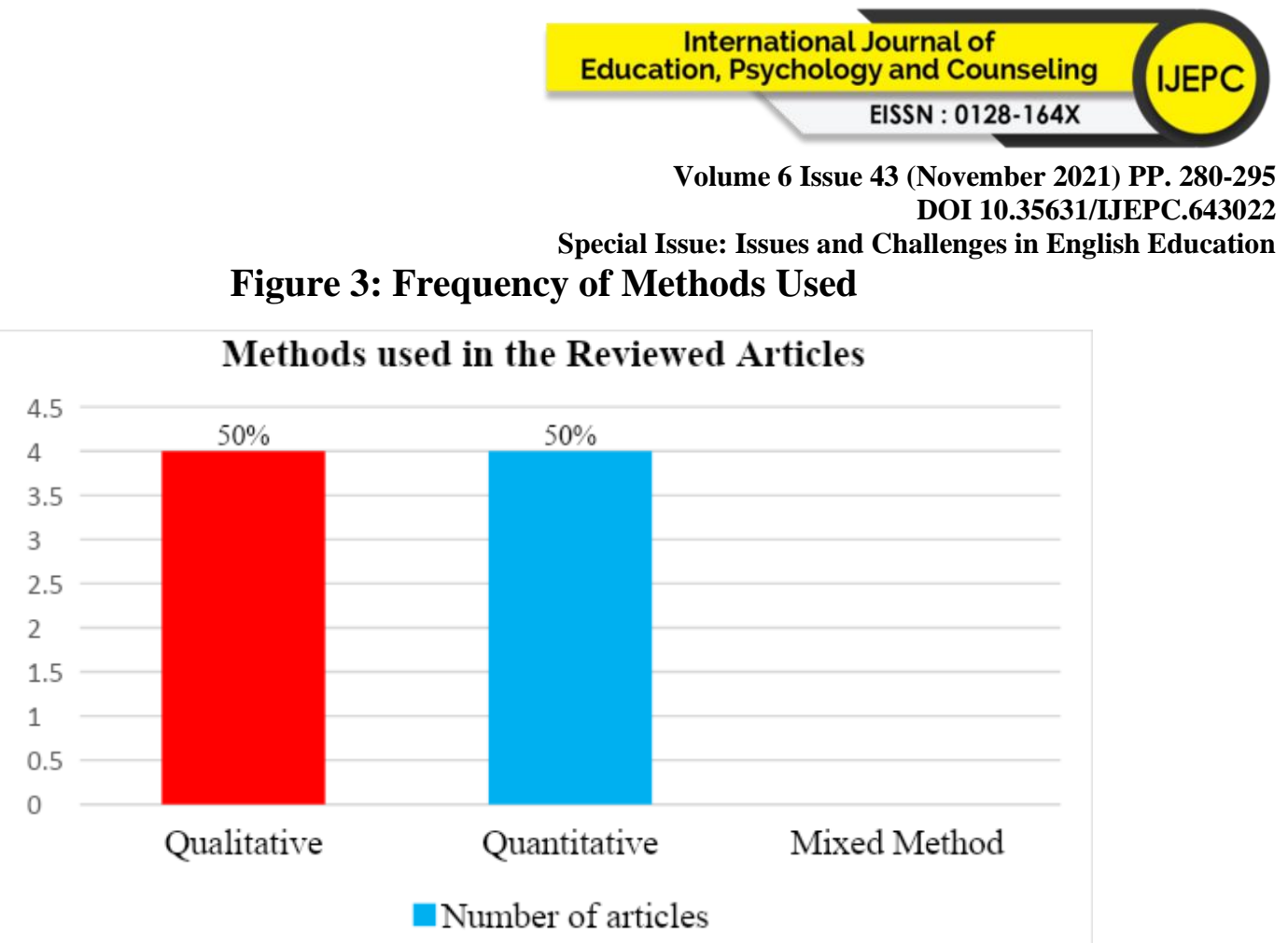

As shown in the figure above, there are an equal number of articles that employed qualitative and quantitative methods which are 4 studies or $50 \%$ respectively. There are no articles that employed mixed methods.

\section{Discussion}

The discussion of the review involves answering the research question. The discussion focuses on the lived experiences of pre-service teachers teaching practicum experiences during the COVID-19 pandemic. After reading and analysing the 8 relevant articles, we found that the pre-service teachers teaching practicum experiences can be categorised into intrapersonal development or interpersonal development. Intrapersonal development mentioned in this study refers to the pre-service teachers' personal experiences regarding their intrapersonal growth during the teaching practicum such as attitudes towards the change hence their readiness and acceptance to the new normal. Interpersonal development refers to the pre-service teachers' growth resulting from their communication with their institutions, university supervisors or mentor teachers. Both aspects are essential and crucial during teaching practicum especially during an unprecedented event that requires the transition of teaching and learning to online.

\section{Intrapersonal Development}

Out of the 8 research articles reviewed, the findings of 5 articles (RA2, RA4, RA5, RA6 and RA8) show that most pre-service teachers are able to respond positively towards online learning and teaching. The pre-service teachers show tendency towards accepting the transition and portray readiness during their teaching practicum in 2 research articles (RA4 and RA6). The pre-service teachers have high motivation and self-directed learning (RA6). They also understood the importance of the role as a teacher and the use of technology to overcome the challenges during a pandemic (RA5). This acceptance and readiness are 


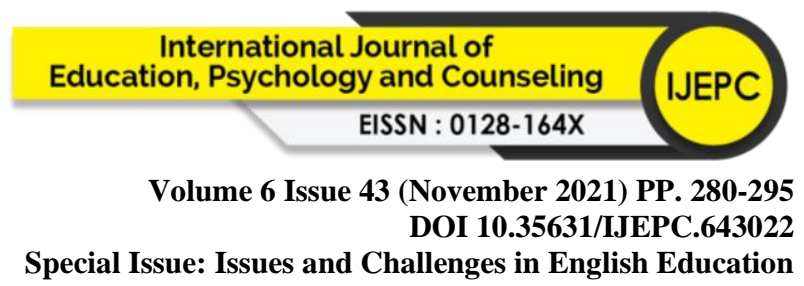

associated with the pre-service teachers' attitudes. In 1 research article (RA2), the results stated that pre-service teachers have a moderate level of self-esteem where they are sometimes not confident in online learning and teaching. However, if the pre-service teachers were able to have a positive attitude towards the change, their self-esteem are higher than those who have a negative attitude towards the change (RA2). One research article (RA8) also stated that the pre-service teachers were quick to adapt and show moderate positivity towards the impact of the change in education but their opinion of the effectiveness of the change is low. Most negative perceptions are towards online teaching and their lack of learner control, IT efficacy and the students' lack of commitment and motivation (RA4 and RA6). Overall, the pre-service teachers seem to have a positive perception towards the change as they understood the importance of the transition from face-to-face learning to online learning during the pandemic.

\section{Interpersonal development}

COVID-19 has presented unexpected challenges and strained educational institutions around the world (Barnes et al., 2020). Sometimes the challenges faced may affect the teaching practicum experiences of pre-service teachers and their professional development. Nonetheless, based on the analysis of reviewed studies, higher education institutions have taken action to provide opportunities for pre-service teachers to experience professional development during teaching practicum. One research article (RA8) shows an educational institution providing opportunities to pre-service teachers by supporting them through the abrupt switch to online learning and teaching with appropriate instructional strategies in courses for teacher education. Moreover, online collaborations with schools and families were also implemented to ensure pre-service teachers' experience an efficient online teaching and learning. One study (RA3) also compiled a list of responses from pre-service teachers towards COVID-19 regarding teaching practicum. The institution fosters communication between pre-service teachers and teacher mentors. Other than that, ensures careful evaluation whether placement schools meet the needs of pre-service teachers and is virtual-friendly during the teaching practicum. Through diligent effort, all of the pre-service teachers were able to complete the teaching practicum. Thus, it is important to have a reliable platform for exchanging constructive feedback between pre-service teachers and mentor teachers or university supervisors. One of the reviewed articles (RA1) shows that providing feedback and having a reliable platform for opportunities can overcome problems during teaching practicum. The pre-service teacher, mentor teachers and university supervisor were actively engaged on the platform and this assisted pre-service teachers to make crucial adjustments to the core practice of teaching. In conclusion, a positive or negative teaching practicum experiences highly depends on the institutions as much as the pre-service teachers depend on themselves. Education institutions can provide guidance and opportunities to pre-service teachers in their professional development.

\section{Implementation}

Based on the findings in the reviewed articles, attitude and self-esteem are important aspects for not only a pre-service teacher but also an educator in order to maintain a good teaching and effective learning process during a pandemic with an inevitable transition from face-toface learning to online learning. A positive attitude and self-esteem can help pre-service Copyright (C) GLOBAL ACADEMIC EXCELLENCE (M) SDN BHD - All rights reserved 


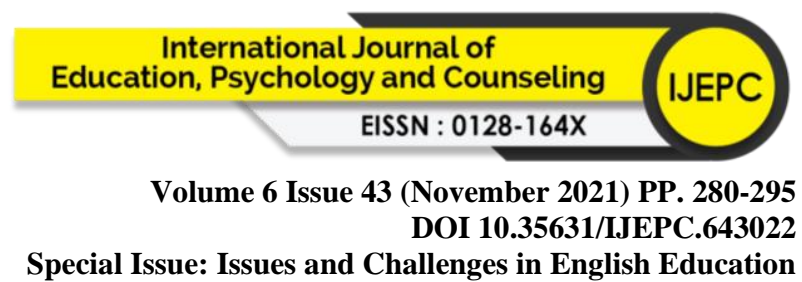

teachers in their acceptability towards the transition and increase motivation and readiness to undergo teaching practicum and preparation for the teaching profession.

Institutional support is vital for this to happen and is a factor that is associated with the impact and effectiveness of online education. Education institutions can foster trust in online learning by introducing the pedagogy for online teaching or student teachers to technology integrated lessons in the courses. The outcomes will be helpful for curriculum and instructional designers to design instructions for better learning of the students. Other than that, providing support such as ensuring a reliable channel for constructive feedback or communication between pre-service teachers, mentor teachers and university supervisors may overcome or even prevent any difficulties of teaching practicum during an emergency situation.

\section{Limitation and Directions for Future Studies}

As observed, there are not many studies related to pre-service teachers' teaching practicum experiences during the COVID-19 pandemic as this issue is relatively new. The pandemic only started a year ago in March 2020 and education programs only carry out teaching practicum once a year, usually the final semester of the program. Future studies may obtain more findings in the future as time proceeds as this study only focuses on articles published within the year 2020 and 2021. Besides that, this systematic literature review only involved 8 articles from 2 databases which are Scopus and ProQuest. Future researchers may include more databases in their search for relevant articles such as ERIC, Science Direct or Google Scholar and more to obtain more articles and broader overview of the study. Most of the studies are also carried out by overseas researchers and lack of studies within the context of Malaysia. Therefore, each finding may differ due to the context of cultural differences. According to Chamberlain (2005), our perceptions of the ways others think and act depend on our cultural perspective, which depends, in part, on our understanding that cultural differences do exist among groups. Other than that, future studies might look at specifying which education program the pre-service teachers are from as pre-service teachers' approach to teaching practicum may vary in terms of pedagogy based on their major subjects.

\section{Conclusion}

Due to the study only focusing on the period of the pandemic and is considered relatively new, there are not many studies yet available thus a limited current research. However, this systematic literature review has a total of 8 relevant articles from 2 databases which are Scopus and ProQuest. Based on the discussion, the findings show that the lived experiences of pre-service teachers teaching practicum experiences during the COVID-19 pandemic are generally positive as most findings show pre-service teachers to have a positive attitude towards the unprecedented transition of face-to-face learning to online learning. Although in the face of challenges and difficulties to the point some may be less motivated and have low self-esteem, pre-service teachers understood their role as an educator and appreciate the use of technology to allow them an opportunity to undergo teaching practicum during the pandemic. Results also show that education institutions also play a big role in the pre-service teachers' experiences as they also strive for solutions to ensure pre-service teachers learning and professional development are achieved. Therefore, this study recommends future 


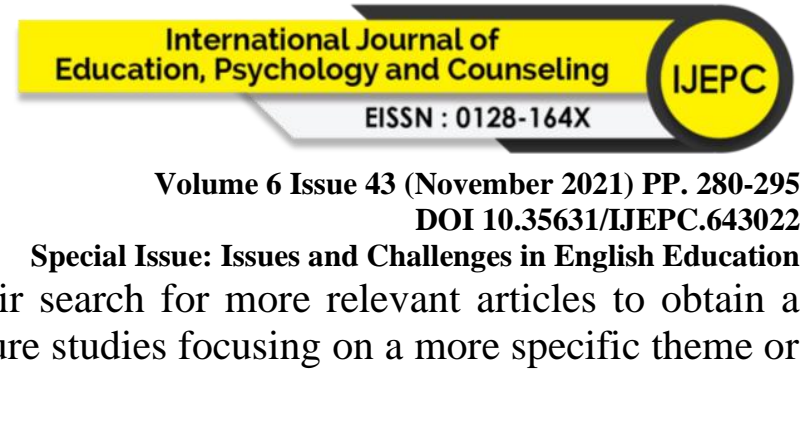

\section{Reference}

Aguilar-Cruz, P. J. \& Medina, D. L. (2021). Pre-service English teachers' perceptions of their online teaching practice during pandemic times. Special number: Education practices and teacher training, 9.

Baran, E. \& Alzoubi, D. (2020). Human-Centered Design as a Frame for Transition to Remote Teaching during the COVID-19 Pandemic. Journal of Technology and Teacher Education, 28(2), 365-372.

Barnes, R., Hall, R., Lowe, V., Pottinger, C. \& Popham, A. (2020). Lessons from an online teacher preparation Program: flexing work experience to meet student needs and regulators' requirements in the United States. Journal of Education for Teaching,46(4), 528-535.

Chamberlain, S. P. (2005). Recognizing and Responding to Cultural Differences in the Education of Culturally and Linguistically Diverse Learners. Intervention in School and Clinic, 40(4), 195-211.

Creswell, J. W. (2012). Educational Research: Planning, Conducting and Evaluating Quantitative and Qualitative Research (4th ed.). Boston, MA: Pearson.

Dorsah, P. (2021). Pre-service teachers Readiness for Emergency Remote Learning on the Wake of COVID-19. European Journal of STEM Edcuation, 6(1), 1-12.

Ersin, P., Atay, D. \& Mede, E. (2020). Boosting Preservice Teachers' Competence and Online Teaching Readiness through E-Practicum during the COVID-19 Outbreak. International Journal of TESOL Studies, 2(2), 112-124.

Kim, J. (2020). Learning and Teaching Online During Covid-19: Experiences of Student Teachers in an Early Childhood Education Practicum. International Journal of Early Childhood, 52, 145-158.

Mengist, W., Soromessa, T. \& Legese, G. (2020). Method for conducting systematic literature review and meta-analysis for environmental science research. MethodsX, 111.

Mohd Rustam Mohd Rameli, Najua Syuhada Ahmad Alhassora, Muhammad Abd Hadi Bunyamin \& Chuzairy Hanri (2020). Student Teachers' Attitude and Self-esteem towards Online Learning: Application of Rasch Measurement Model. Universal Journal of Education Research, 8(11), 37-44.

Muhammad Zaheer Asgahr, Elena Barbera \& Iram Younas (2021). Mobile learning technology readiness and acceptance among pre-service teachers in Pakistan during the COVID-19 pandemic. Knowledge Management \& E-Learning, 13(1), 83-101.

Nel, C. \& Marais, E. (2021). Addressing the Wicked Problem of Feedback During the Teaching Practicum. Perspective in Education, 39(1), 410-426.

Ogbonnaya, U. I., Awoniyi, F. C. \& Matabane, M. E. (2020). Move to Online Learning during COVID-19 Lockdown: Pre-Service Teachers' Experiences in Ghana. International Journal of Learning, Teaching and Educational Research, 19(10), 286303. 


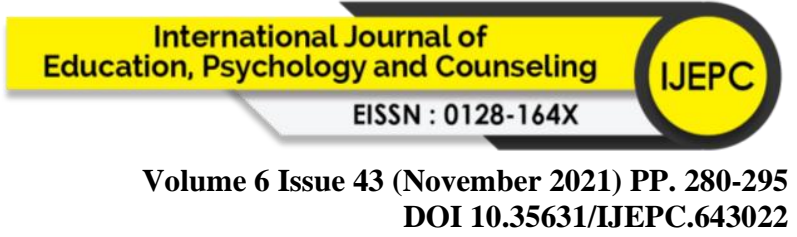

Special Issue: Issues and Challenges in English Education

Sasaki, R., Goff, W., Dowsett, A., Paroissien, D., Matthies, J., Di Iorio, C., Montey, S., Rowe, S. \& Puddy, G. (2020). The Practicum Experience during Covid-19 Supporting Initial Teacher Education Student's Practicum Experience Through a Simulated Classroom. Journal of Technology and Teacher Education, 28(2), 329-339.

Singhal, T. (2020). A Review of Coronavirus Disease-2019 (COVID-19). The Indian Journal of Pediatrics, 87(4), 281-286.

Tartavulea, C. V., Albu, C. N., Albu, N., Dieaconescu, R. I. \& Petre, Silvia. (2020). Online Teaching Practices and the Effectiveness of the Educational Process in the Wake of the COVID-19 Pandemic. Amfiteatru Economic, 22(55), 920-936. 